\title{
UJI EFEKTIVITAS ANTIBAKTERI EKSTRAK DAUN JARAK PAGAR (Jatropha curcas Linn) TERHADAP BAKTERI Staphyloccocus aureus
}

\author{
Nursahfitri ${ }^{1}$, Risnanda Amalia ${ }^{2}$, Qori Fadillah ${ }^{3}$ \\ ${ }^{1,2,3}$ Program Studi Pendidikan Dokter, Fakultas Kedokteran, Universitas Prima Indonesia \\ nursahfitri99@gmail.com
}

\begin{abstract}
Abstrak
Penelitian ini bertujuan untuk mengetahui efektivitas dari ekstrak daun jarak pagar (Jatropha curcas L) dengan konsentrasi 30\%, 50\%, 70\%, 90\% dan 100\% terhadap bakteri Staphylococcus aureus dengan antibotik amoxicillin-clavulanic acid sebagai pembanding. Jenis penelitian yang digunakan adalah true experiment dengan desain posttest only. Uji efektivitas antibakteri ekstrak daun jarak pagar (Jatropha curcas L) terhadap bakteri Staphylococcus aureus dengan cara difusi agar/Kirby-bauer memakai kertas cakram yang didalamnya terdapat ekstrak daun jarak pagar kemudian diletakkan ke media kultur (MHA) metode ini berguna untuk mengamati diameter zona hambat ekstrak kemudian hasilnya batch-to-batch yang baik. Metode pengolahan data yang digunakan dalam uji coba penelitian adalah Shapiro-Wilk yaitu oneway ANOVA untuk mengetahui efek antibakteri dari ekstrak daun jarak pagar dan uji Least Significant Difference (LSD) untuk mengetahui perbedaan efek antibakteri antar 2 kelompok perlakuan. Dari uji tersebut menunjukkan bahwa data penelitian berdistribusi normal dikarenakan $p>0,05$ pada uji statistik oneway ANOVA menunjukkan nilai $p=0,000(p<0,05)$ yaitu ada perbedaan yang signifikan efek antibakteri ekstrak daun jarak pagar (Jatropha curcas L) terhadap bakteri Staphylococcus aureus pada hasil analisis uji posthoc LSD menunjukkan bahwa ada perbedaan yang signifikan antara kelompok ekstrak dengan kelompok perlakuan ekstrak lainnya.
\end{abstract}

Kata Kunci : Staphylococcus aureus, Jatropha curcas L, Ekstrak Daun Jarak Pagar

\begin{abstract}
This study aims to determine the effectiveness of jatropha leaf extract (Jatropha curcas $\mathrm{L}$ ) with a concentration of $30 \%, 50 \%, 70 \%, 90 \%$ and $100 \%$ against bacteria Staphylococcus aureus with amoxicillin-clavulanic acid as a comparison. The type of research used is true experiment with design posttest only. Antibacterial effectiveness test of leaf extract Jatropha curcas (Jatropha curcas L) against Staphylococcus aureus by agar/Kirby-bauer diffusion using disc paper in which there is jatropha leaf extract then put into culture media (MHA) this method is useful for observing the diameter of the inhibition zone extract then the results are batch-to-batch good. The data processing method used in the research trial was Shapiro-Wilk, namely oneway ANOVA to determine the antibacterial effect of jatropha leaf extract and the Least Significant Difference (LSD) test to determine the difference in antibacterial effects between the 2 treatment groups. From this test, it shows that the research data is normally distributed because $p>0.05$ in the statistical test oneway ANOVA shows a value of $p=0.000$ $(p<0.05)$, that is, there is a significant difference in the antibacterial effect of jatropha leaf extract (Jatropha curcas L) on bacteria. Staphylococcus aureus in thean alysis results posthoc LSD showed that there was a significant difference between the extract group and the other extract treatment groups.
\end{abstract}

Keywords: Staphylococcus aureus, Jatropha curcas L, Jatropha Leaf Extract 


\section{PENDAHULUAN}

Penyakit paru merupakan penyakit yang sangat berbahaya dikarenakan tingkat penularannya terjadi sangat cepat. Masyarakat Indonesia sangat minim pengetahuan akan bahaya penyakit paru-paru dan gejala yang dialaminya sehingga apabila dibiarkan tanpa pengobatan yang tepat akan berisiko penularan penyakit bahkan menyebabkan kematian $\left({ }^{1}\right)$. Menurut penelitian Esti Rahmawati, penyakit paru yang paling sering diderita masyarakat Indonesia hanyalah : Tuberkulosis Paru (TBC), Penyakit Paru Obstruktif Kronik (PPOK), Asma Bronkial, Kanker Paru dan Pneumonia( $\left.{ }^{2}\right)$.

Produk tembakau non rokok dapat meningkatkan faktor risiko penularan penyakit. Dari penelitian yang dilakukan di Saudi Arabia terdapat 55 jenis bakteri pada produk tembakau non rokok yaitu terdiri dari 28 jenis bakteri gram positif dan 27 jenis bakteri gram negatif. Disana ditemukan bakteri Staphylococcus aureus dimana bakteri tersebut merupakan bakteri yang resisten terhadap antibiotik $\left({ }^{3}\right)$

Infeksi yang disebabkan oleh bakteri patogen yang memiliki resistensi terhadap antibiotik memiliki peningkatan perawatan kesehatan dan infeksi yang di dapat masyarakat. Resistensi antibiotik merupakan ancaman serius dan sangat berkembang terhadap kesehatan masyarakat dan penyediaan perawatan kesehatan di seluruh dunia. Faktor kemunculan penyebaran resistensi antibiotik di seluruh dunia termasuk dalam penggunaan antibiotik yang tidak tepat, pengaturan layanan kesehatan dalam pemberian resep dan masyarakat menggunakan secara luas sehingga meningkatnya jumlah individu yang mengalami gangguan kekebalan, meningkatnya perjalanan global dan migrasi dari negara-negara yang memiliki tingkat patogen yang resistensi antibiotik lebih tinggi dengan jumlah antibiotik yang baru tidak memadai dalam perkembangannya. Berdasarkan tabel Antibiotic-resistant bacteria in the United States of America, Europe and the world pada tahun $2015 \mathrm{di}$ Eropa bakteri Staphylococcus aureus (17\%) mengalami resistensi terhadap obat antibiotik $\left({ }^{4}\right)$.

Di Indonesia, dari tabel data surveilans mikroba pada rumah sakit tipe A/tipe perawatan intensif dengan pengujian laboratorium spesimen darah Staphylococcus aureus jenis gram positif resistensi terhadap amoxicillin-clavulanic acid $(83,3 \%)$, ampicillin sulbactam $(91,7 \%)$, cefepime $(91,7 \%)$, cefoxitin $(100 \%)$, ceftazidime $(83,3 \%)$, ceftriaxone (83,3\%), ciprofloxacin (75\%), clarithromycin (91,7\%), ertapenem (75\%), erythromycin (91,7\%), gentamicin (87,5\%), imipenem $(87,5 \%)\left({ }^{5}\right)$.

Bakteri gram positif Staphylococcus aureus adalah merupakan bakteri yang flora normal ada di kulit $\left(^{6}\right)$. Selain itu ada pula yang sifatnya patogen oportunistik dapat menginfeksi sehingga menyebabkan penyakit sepsis, endokarditis, pneumonia, gastroenteritis, abses dan osteomielitis $\left({ }^{7}\right)$.

Banyaknya efek samping yang ditimbulkan dari antibiotik maka banyak orang-orang memakai tanaman obat tradisional sebagai alternatif untuk mengatasi penyakit infeksi $\left({ }^{8}\right)$. Masyarakat Indonesia sejak dulu sudah memanfaatkan tumbuhan sekitar untuk memenuhi kebutuhannya seperti makanan, kecantikan dan berbagai masalah kesehatan. Hal ini mudah dilakukan, mengingat tumbuhan dapat ditanam di berbagai tempat dan tidak membutuhkan lahan yang begitu luas. Bahan alam juga dipercaya digunakan sejak dahulu oleh masyarakat karena mampu mengobati penyakit tanpa menimbulkan efek samping yang serius dibandingkan dengan obat yang menggunakan bahan sintesis $\left({ }^{9}\right)$.

Pada tanaman jarak pagar (Jatropha curcas L) mampu menjadi tanaman antimikroba karena memiliki senyawa metabolit latex sebagai komponen utamanya. Disamping itu terdapat senyawa metabolit, tanin, polifenol dan polisakarida sebagai inhibitor enzim. Diketahui bahwa daun jarak pagar bersifat antiparasitik sedangkan ekstrak daun jarak serta bijinya dilaporkan sebagai antibakteri. Pada bagian daun jarak dan kulit batangnya diketahui unsur yang paling banyak berupa tanin, flavonoid, cardiac glycoside, phlobatannin, terpenoid dan alkaloid. Namun hal tersebut bergantung terhadap konsentrasi daun jarak, mikroba dan bagian yang digunakan. Tanin dengan protein yang kaya prolin membentuk komplek irreversible menghambat sintesis protein $\left({ }^{10}\right)$.

Tanaman daun jarak pagar bagian daun, buah dan batang dapat menghambat bakteri Staphylococcus aureus dikarenakan mengandung senyawa flavoid sebagai penghambat sintesis protein yang bersifat anti mikroba, anti alergi, antiinflamasi, anti oksidan dan analgesik $\left({ }^{10}\right)$. Berdasarkan permasalahan di atas, maka perlu dilakukan dan dikembangkan penelitian mengenai efektivitas ekstrak daun jarak pagar (Jatropha curcas L) sebagai antibakteri terhadap bakteri Staphylococcus aureus. 


\section{METODE}

Jenis penelitian yang digunakan adalah true experiment dengan desain posttest only yang bertujuan untuk mengetahui efektivitas antibakteri ekstrak daun jarak pagar (Jatropha curcas L) konsentrasi 30\%, 50\%,70\%, 90\% dan 100\% terhadap bakteri Staphylococcus aureus. Lokasi untuk membuat ekstrak dikerjakan di Laboratorium Obat Tradisional Fakultas Farmasi Universitas Sumatera Utara di bulan juni. Sedangkan untuk melihat efektivitas ekstrak sebagai antibakteri pada bakteri Staphylococcus aureus dilakukan di Laboratorium Universitas Prima Indonesia pada bulan September. Sampel yang digunakan dalam penelitian ini adalah daun jarak pagar (Jatropha curcas L) berasal dari pohon jarak pagar yang didaptkan di Desa Sidodadi, Kabupaten Aceh Tamiang. Bakteri Staphylococcus aureus dibeli dari Laboraturium Mikrobiologi FMIPA USU. Alat-alat yang digunakan dalam penelitian ini adalah Rotary evaporator, beaker glass, cawan petri, incubator, waterbath, laminar air flow, vortex mixer, cakram kertas. Bahan penelitian yang akan digunaan adalah daun jarak pagar (Jatropha curcas L), bakteri Staphylococcus aureus, antibiotik amoxicillin-clavulanic acid, DMSO (dimetil sulfoxida), media MHA (Muller Hinton Agar).

Prosedur Penelitian

Pembuatan Ekstrak Daun Jarak Pagar (Jatropha curcas L)

Metode pembuatan ekstrak daun jarak pagar menggunakan metode maserasi.

1. Timbang 500 gram serbuk simplisia kemudian masukan ke dalam wadah bertutup masukan etanol 70\% 5 liter aduk terus selama 6 jam. Diamkan 18 jam sesekali aduk.

2. Kemudian lakukan penyaringan dengan kertas saring dan kapas, zat hasil penyaringan merupakan maserat I. Ulangi pada ampas dengan etanol 70\% 2,5 liter merupakan maserat II.

3. Gabungkan maserat I dan II. Uapkan maserat menggunakan waterbath sederhana pada $90^{\circ} \mathrm{C}$. Diaduk-aduk hingga ekstrak mengental. Ekstrak yang kental masukan kedalam wadah $\left({ }^{11}\right)$.

Pembuatan Konsetrasi Ekstak Daun Jarak Pagar (Jatropha curcas L)

1. Ekstrak kental daun jarak pagar yang diperoleh kemudian dibagi menjadi lima konsentrasi, yaitu $30 \%$, 50\%, 70\%, 90\% dan $100 \%$ dengan menggunakan pengenceran DMSO.

2. Timbang ekstrak kental daun jarak pagar sesuai konsentrasi lalu masukkan ke dalam gelas ukur menggunakan spatula, kemudian masukkan DMSO hingga memenuhi gelas ukur sebanyak $10 \mathrm{ml}$ tidak kurang dan tidak lebih lalu diaduk.

3. Pindahkan ke dalam vial yang telah diberi label. (kontrol positif) antibiotik amoxicillinclavulanic acid sedangkan DMSO (kontrol negatif).

\section{Langkah - langkah Penelitian}

1. Media MHA dibuat dengan cara melarutkan 34 gram muller hinton agar dalam 1 liter akuades kemudian sterilisasikan media dengan menggunakan autoclave pada suhu $121^{\circ} \mathrm{C}$ dalam waktu 20 menit. Lalu media MHA diletakkan pada cawan petri yang telah steril dan didiamkan pada suhu kamar hingga memadat $\left({ }^{12}\right)$.

2. Metode Disc Diffusion (Kirby-Bauer) dilakukan untuk menguji bakteri Staphylococcus aureus.

3. Suspensi bakteri dimasukkan pada media cawan petri lalu goreskan diatas media uji dengan menggunakan kapas ulas steril kemudian di putar beberapa kali dan dilakukan sebanyak dua kali.

4. Cakram kertas berisi konsentrasi ekstrak daun jarak pagar, kontrol positif dan kontrol negatif diletakan di tempat di atas permukaan cakram yang sesuai dengan posisi yang telah diatur.

5. Kemudian inkubasi media tersebut dalam $37^{\circ} \mathrm{C}$ selama 24 jam. Lakukan pengamatan terhadap diameter zona hambat dalam satuan millimeter menggunakan jangka sorong $\left({ }^{13}\right)$.

\section{Analisis data}

Setelah didapatkan hasil penelitian diameter zona hambat ekstrak konsentrasi 30\%, 50\%, 70\%, 90\%, 100\% terhadap bakteri Staphylococcus aureus dengan menggunakan metode difusi yang dilakukan sebanyak 4 kali pengulangan untuk setiap kelompok maka dilakukan pengelolahan data dengan uji normalitas Shapiro-Wilk dan dilanjutkan dengan uji statistic parametric oneway ANOVA dan posthoc LSD.

HASIL

Hasil Skrining Fitokimia Ekstrak Daun Jarak Pagar (Jatropha curcas L)

Pada ekstrak daun jarak pagar (Jatropha curcas L) dilakukan pengujian skrining fitokimia sehingga didapatkan hasil seperti tabel dibawah ini:

Tabel 1. Hasil Skrining Fitokimia Ekstrak Daun Jarak Pagar (Jatropha curcas L)

\begin{tabular}{llll}
\hline No & Parameter & Hasil & Tanda \\
\hline 1 & Saponin & Negtif & - \\
2 & Steroida & Positif & + \\
3 & Triterpenoid & Positif & +
\end{tabular}



Vol. 5/No.4/Oktober 2020; ISSN:2502-731X

$\begin{array}{llll}4 & \text { Alkaloida } & \text { Positif } & + \\ 5 & \text { Flavonoida } & \text { Positif } & + \\ 6 & \text { Tanin } & \text { Positif } & +\end{array}$

Berdasarkan tabel 1 diatas, hasil penelitian tentang uji skrining fitokimia menunjukkan bahwa terkandung zat metabolit sekunder berupa alkaloid, steroida, triterpenoid, flavonoida, tanin. Metode pengujian kandungan senyawa bersifat kualitatif dimana hanya untuk mendeteksi ada atau tidaknya senyawa metabolit pada penelitian ini.

\section{Hasil Pengukuran Diameter Zona Hambat Ekstrak}

Dalam penelitian ini seluruh konsentrasi menghasilkan zona hambat. Hasil selengkapnya dapat dilihat pada gambar 1, 2, 3, 4 dibawah ini.

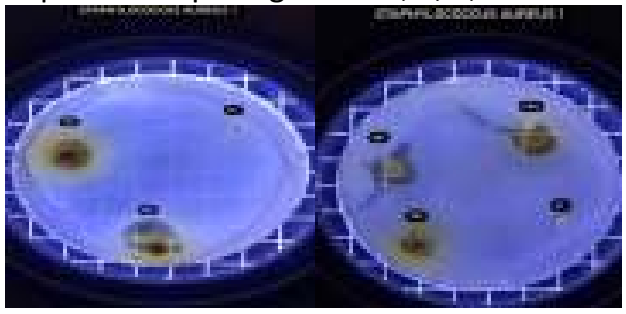

Gambar 1. Pengulangan 1 dengan konsentrasi 30\%, 50\%, 70\%, 90\%, 100\%, kontrol positif (Amoxicillinclavulanic acid) dan kontrol negatif (DMSO)

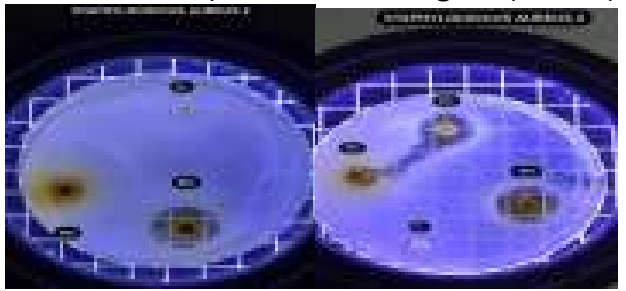

Gambar 2. Pengulangan 2 dengan konsentrasi 30\%, 50\%, 70\%, 90\%, 100\%, kontrol positif (Amoxicillinclavulanic acid) dan kontrol negatif (DMSO)

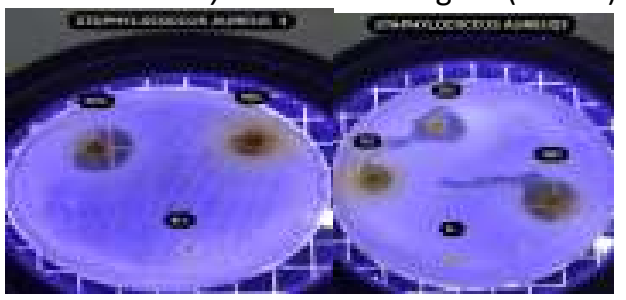

Gambar 3. Pengulangan 3 dengan konsentrasi 30\%, 50\%, 70\%, 90\%, 100\%, kontrol positif (Amoxicillinclavulanic acid) dan kontrol negatif (DMSO)

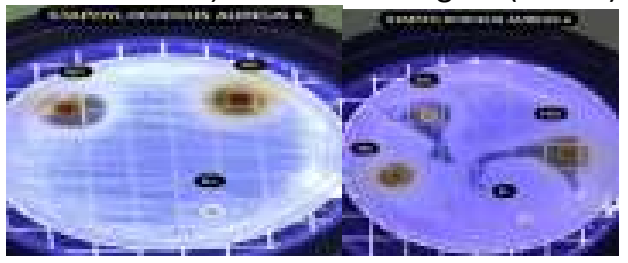

Gambar 4. Pengulangan 4 dengan konsentrasi 30\%, 50\%, 70\%, 90\%, 100\%, kontrol positif (Amoxicillinclavulanic acid) dan kontrol negatif (DMSO)

Pengujian dilakukan pada ekstrak dengan konsentrasi 30\%, 50\%, 70\%, 90\%, 100\% dan kontrol positif (Amoxicillin-clavulanic acid) membentuk zona bening sekitaran kertas cakram pada media MHA yang menandakan adanya zona hambat dengan bakteri, sedangkan kontrol negatif (DMSO) tidak ditemukan zona bening.

Tabel 2. Hasil Diameter Zona Hambat Ekstrak

\begin{tabular}{|c|c|c|c|c|c|c|c|}
\hline \multirow{2}{*}{$\begin{array}{l}\text { Peng } \\
\text { ulang } \\
\text { an }\end{array}$} & \multicolumn{5}{|c|}{$\begin{array}{l}\text { Diameter Zona Hambat }(\mathrm{mm}) \\
\text { konsentrasi ekstrak }\end{array}$} & \multirow{2}{*}{ K- } & \multirow{2}{*}{$\mathrm{K}+$} \\
\hline & $30 \%$ & $50 \%$ & $70 \%$ & $90 \%$ & $\begin{array}{l}100 \\
\%\end{array}$ & & \\
\hline 1 & $\begin{array}{l}12, \\
1\end{array}$ & $\begin{array}{l}13, \\
9\end{array}$ & $\begin{array}{l}15, \\
1\end{array}$ & $\begin{array}{l}19, \\
6\end{array}$ & 21,9 & 0 & 7,7 \\
\hline 2 & $\begin{array}{l}15, \\
4\end{array}$ & $\begin{array}{l}15, \\
5\end{array}$ & $\begin{array}{l}18, \\
0\end{array}$ & $\begin{array}{l}15, \\
3\end{array}$ & 21,1 & 0 & 8,5 \\
\hline 3 & $\begin{array}{l}15, \\
0\end{array}$ & $\begin{array}{l}16 \\
5\end{array}$ & $\begin{array}{l}13, \\
5\end{array}$ & $\begin{array}{l}18, \\
3\end{array}$ & 18,0 & 0 & 0 \\
\hline 4 & $\begin{array}{l}15, \\
0\end{array}$ & $\begin{array}{l}11, \\
9\end{array}$ & $\begin{array}{l}12, \\
9\end{array}$ & $\begin{array}{l}18 \\
5\end{array}$ & 18,5 & 0 & 0 \\
\hline $\begin{array}{l}\text { Rerat } \\
\text { a }\end{array}$ & $\begin{array}{l}14, \\
375\end{array}$ & $\begin{array}{l}14, \\
450\end{array}$ & $\begin{array}{l}14, \\
875\end{array}$ & $\begin{array}{l}17, \\
925\end{array}$ & $\begin{array}{l}19,8 \\
00\end{array}$ & 0 & $\begin{array}{l}4,05 \\
0 \\
\end{array}$ \\
\hline SD & $\begin{array}{l}1,5 \\
283\end{array}$ & $\begin{array}{l}2,0 \\
091\end{array}$ & $\begin{array}{l}2,2 \\
809\end{array}$ & $\begin{array}{l}1,8 \\
410\end{array}$ & $\begin{array}{l}1,91 \\
55\end{array}$ & 0 & $\begin{array}{l}4,68 \\
79\end{array}$ \\
\hline
\end{tabular}

*keterangan $\mathrm{K}$ - : kontrol negatif (DMSO)

$\mathrm{K}+$ : kontrol positif (Amoxicillin-clavulanic acid) Berdasarkan tabel 2 diatas, hasil penelitian menunjukkan bahwa nilai rerata diameter zona hambat dengan ekstrak konsentrasi 30\%, 50\%, 70\%, $90 \%, 100 \%$ dan kontrol positif (Amoxicillinclavulanic acid) dalam menghambat Staphylococcus aureus adalah 14,375 $\pm 1,5283 \mathrm{~mm} ; 14,450 \pm 2,0091$ $\mathrm{mm} ; 14,875 \pm 2,2809 \mathrm{~mm} ; 17,925 \pm 1,8410 \mathrm{~mm}$; $19,800 \pm 1,9155 \mathrm{~mm} ; 4,050 \pm 4,6879 \mathrm{~mm}$. sedangkan kontrol negatif (DMSO) tidak memiliki hambatan.

Tabel 3. Hasil Uji Normalitas

\begin{tabular}{lll}
\hline Konsentrasi & $p$ value & Keterangan \\
\hline $30 \%$ & 0,027 & Tidak normal \\
$50 \%$ & 0,842 & Normal \\
$70 \%$ & 0,489 & Normal \\
$90 \%$ & 0,332 & Normal \\
$100 \%$ & 0,340 & Normal \\
Kontrol positif & 0,580 & Normal \\
Kontrol negatif & 0 & - \\
\hline
\end{tabular}

*ket : Kontrol Positif(Amoxicillin-clavulanic acid) Kontrol Negatif (DMSO)

Berdasarkan tabel 3 diatas, hasil uji normalitas dengan Shapiro-Wilk menunjukkan bahwa data penelitian ini berdistribusi normal dikarenakan nilai $p>0,05$. Analisa dilanjutkan dengan uji statistik parametrik oneway ANOVA dan posthoc LSD.

Hasil uji oneway ANOVA digunakan untuk melihat efek antibakteri ekstrak daun jarak pagar (Jatropha curcas L) konsentrasi 30\%, 50\%, 70\%, 90\%, 100\%, kontrol positif (Amoxicillin-clavulanic 
acid) dan kontrol negatif (DMSO) terhadap bakteri Staphylococcus aureus dapat dilihat pada tabel 4 berikut ini.

Tabel 4. Hasil Uji Oneway ANOVA

\begin{tabular}{llll}
\hline Kelompok & $\bar{x} \pm 50$ & $p$ value & $\begin{array}{l}\text { Keteranga } \\
\mathrm{n}\end{array}$ \\
\hline $30 \%$ & $14,375 \pm 1,528$ & & \\
& $3 \mathrm{~mm}$ & \\
$50 \%$ & $14,450 \pm 2,009$ & & \\
& $1 \mathrm{~mm}$ & \\
$70 \%$ & $14,875 \pm 2,280$ & & Ada perbedaa \\
& $9 \mathrm{~mm}$ & $\mathrm{n}$ yang \\
$90 \%$ & $17,925 \pm 1,841$ & $0,000^{*}$ & signifikan \\
& $0 \mathrm{~mm}$ & & \\
$100 \%$ & $19,800 \pm 1,915$ & & \\
& $5 \mathrm{~mm}$ & & \\
Kontrol & $4,050 \pm 4,6879$ & & \\
positif & $\mathrm{mm}$ & & \\
Kontrol & 0 & & \\
negatif & & & \\
\hline Keterangan & $*$ terdapat perbedaan yang signifikan
\end{tabular}

Keterangan $*$ terdapat perbedaan yang signifikan $(p<0,05)$

Berdasarkan tabel 4 diatas, hasil uji statistik oneway ANOVA menunjukkan bahwa nilai $p=0,000$ $(p<0,05)$ dinyatakan bahwa uji penelitian ini diterima yaitu ada perbedaan yang signifikan efek antibakteri ekstrak daun jarak pagar (Jatropha curcas L) terhadap bakteri Staphylococcus aureus. Selanjutnya, data dianalisis menggunakan uji posthoc LSD yang bertujuan mengetahui perbedaan efek antibakteri antara 2 kelompok perlakuan. Hasil penelitian selengkapnya dapat dilihat pada tabel 5 berikut ini.

Tabel 5. Hasil Uji Posthoc LSD

\begin{tabular}{|c|c|c|c|c|}
\hline Kelompok & & $\begin{array}{l}p \\
\text { value }\end{array}$ & Keterangan & \\
\hline $\begin{array}{l}\text { Ekstrak } 30 \% \\
\text { ekstrak } 50 \%\end{array}$ & - & 0,965 & $\begin{array}{l}\text { Tidak } \\
\text { perbedaan }\end{array}$ & ada \\
\hline $\begin{array}{l}\text { Ekstrak } 30 \% \\
\text { ekstrak } 70 \%\end{array}$ & - & 0,772 & $\begin{array}{l}\text { Tidak } \\
\text { perbedaan }\end{array}$ & ada \\
\hline $\begin{array}{l}\text { Ekstrak } 30 \% \\
\text { ekstrak } 90 \%\end{array}$ & - & 0,050 & $\begin{array}{l}\text { Tidak } \\
\text { perbedaan }\end{array}$ & ada \\
\hline $\begin{array}{l}\text { Ekstrak } 30 \% \\
\text { ekstrak } 100 \%\end{array}$ & - & $0,004^{*}$ & Ada perbedaan & \\
\hline $\begin{array}{l}\text { Ekstrak } 30 \% \\
\text { kontrol positif }\end{array}$ & - & $0,000^{*}$ & Ada perbedaan & \\
\hline $\begin{array}{l}\text { Ekstrak } 30 \% \\
\text { kontrol negatif }\end{array}$ & - & $0,000^{*}$ & Ada perbedaan & \\
\hline $\begin{array}{l}\text { Ekstrak } 50 \% \\
\text { ekstrak } 70 \%\end{array}$ & - & 0,805 & $\begin{array}{l}\text { Tidak } \\
\text { perbedaan }\end{array}$ & ada \\
\hline $\begin{array}{l}\text { Ekstrak } 50 \% \\
\text { ekstrak } 90 \%\end{array}$ & 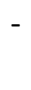 & 0,054 & $\begin{array}{l}\text { Tidak } \\
\text { perbedaan }\end{array}$ & ada \\
\hline $\begin{array}{l}\text { Ekstrak } 50 \% \\
\text { ekstrak } 100 \%\end{array}$ & & $0,000^{*}$ & Ada perbedaan & \\
\hline
\end{tabular}

\begin{tabular}{|c|c|c|c|}
\hline $\begin{array}{l}\text { Ekstrak } 50 \% \\
\text { kontrol positif }\end{array}$ & - & $0,000^{*}$ & Ada perbedaan \\
\hline $\begin{array}{l}\text { Ekstrak } 50 \% \\
\text { kontrol negatif }\end{array}$ & - & $0,000^{*}$ & Ada perbedaan \\
\hline $\begin{array}{l}\text { Ekstrak } 70 \% \\
\text { ekstrak } 90 \%\end{array}$ & - & 0,088 & $\begin{array}{ll}\text { Tidak } & \text { ada } \\
\text { perbedaan } & \end{array}$ \\
\hline $\begin{array}{l}\text { Ekstrak } 70 \% \\
\text { ekstrak 100\% }\end{array}$ & - & $0,008^{*}$ & Ada perbedaan \\
\hline $\begin{array}{l}\text { Ekstrak } 70 \% \\
\text { kontrol positif }\end{array}$ & - & $0,000^{*}$ & Ada perbedaan \\
\hline $\begin{array}{l}\text { Ekstrak } \quad 70 \% \\
\text { kontrol negatif }\end{array}$ & - & $0,000^{*}$ & Ada perbedaan \\
\hline $\begin{array}{l}\text { Ekstrak } 90 \% \\
\text { ekstrak } 100 \%\end{array}$ & - & 0,265 & $\begin{array}{ll}\text { Tidak } & \text { ada } \\
\text { perbedaan } & \end{array}$ \\
\hline $\begin{array}{l}\text { Ekstrak } 90 \% \\
\text { kontrol positif }\end{array}$ & - & $0,000^{*}$ & Ada perbedaan \\
\hline $\begin{array}{l}\text { Ekstrak } 90 \% \\
\text { kontrol negatif }\end{array}$ & & $0,000^{*}$ & Ada perbedaan \\
\hline $\begin{array}{l}\text { Ekstrak } 100 \% \\
\text { kontrol positif }\end{array}$ & - & $0,000^{*}$ & Ada perbedaan \\
\hline $\begin{array}{l}\text { Ekstrak } 100 \% \\
\text { kontrol negatif }\end{array}$ & - & $0,000^{*}$ & Ada perbedaan \\
\hline $\begin{array}{l}\text { Kontrol positif } \\
\text { kontrol negatif }\end{array}$ & & $0,027^{*}$ & Ada perbedaan \\
\hline
\end{tabular}

Keterangan*: terdapat perbedaan yang signifikan $(p<0,05)$

\section{DISKUSI}

Menurut Qori Fadillah $\left({ }^{14}\right)$, klasifikasi respon hambatan ekstrak terhadap pertumbuhan bakteri dibagi atas diameter zona terang $>20 \mathrm{~mm}$ berarti respon hambatan pertumbuhan kuat, diameter zona terang $16-20 \mathrm{~mm}$ berarti respon hambatan pertumbuhan sedang, diameter zona terang 10-15 $\mathrm{mm}$ respon hambatan pertumbuhan lemah sedangkan diameter zona terang $<10 \mathrm{~mm}$ respon hambatan pertumbuhan tidak ada. Berdasarkan hasil penelitian diperoleh ekstrak daun jarak pagar (Jatropha curcas L) konsentrasi 30\%, 50\% dan 70\% diklasifikasikan respon hambatan yang lemah terhadap bakteri Staphylococcus aureus, sedangkan ekstrak konsentrasi $90 \%$ dan $100 \%$ diklasifikasikan respon hambatan yang sedang. Sementara, pada kontrol positif (Amoxicillin clavulanic acid) dan kontrol negatif (DMSO) tidak memiliki respon hambatan. Hasil penelitian ini sejalan dengan penelitian sebelummya menyatakan bahwa ekstrak daun jarak pagar konsentrasi $20 \%, 40 \%, 60 \%, 80 \%$ dan $100 \%$ memiliki daya hambatan yang kuat terhadap bakteri Staphylococcus aureus rerata dengan diameter hambatnya yaitu 13,5 mm, 14,25 $\mathrm{mm}, 18,5 \mathrm{~mm}, 19,5 \mathrm{~mm}$ dan $20,75 \mathrm{~mm}\left({ }^{8}\right)$.

Dalam penelitian ini semakin meningkat tingginya konsentrasi ekstrak, maka semakin besar 
respon hambatannya dalam penghambatan pertumbuhan bakteri Staphylococcus aureus Konsentrasi efektif dalam penghambatan bakteri ini adalah konsentrasi $100 \%$ karena zona diameter penghambatnya paling besar dibandingkan dengan konsentrasi lainnya.

Berdasarkan hasil uji statistik oneway ANOVA dinyatakan bahwa ekstrak daun jarak pagar mempunyai efek antibakteri dengan pertumbuhan bakteri Staphylococcus aureus secara signifikan dengan nilai $p=0,000 \quad(p<0,05)$. Hasil tersebut didukung oleh uji posthoc test LSD diperoleh bahwa terdapat perbedaan efek antibakteri yang signifikan antar kelompok perlakuan dengan masing-masing nilai $p<0,05$. Hasil penelitian ini tidak sejalan dengan penelitian sebelumnya yang menyatakan bahwa konsentrasi ekstrak 30\% tidak bisa menghambat pertumbuhan bakteri $\left({ }^{15}\right)$.

Adanya efektivitas ekstrak dengan konsentrasi 30\%, 50\%, 70\%, 90\% dan 100\% terhadap bakteri Staphylococcus aureus dalam uji ini disebabkan kandungan aktif sebagai antibakteri. Salah satu kandungan aktif yang terkandung ekstrak daun jarak pagar (Jatropha curcas L) adalah alkaloid. Menurut Tiwa $\operatorname{dkk}\left({ }^{9}\right)$, kemampuan alkaloid juga sebagai antibakteri mengganggu susunan zat peptidoglikan sel agar dinding sel bakteri mengalami kegagalan pembentukan dan mengakibatkan lisis.

Mekanisme kerja senyawa tanin dalam ekstrak daun jarak pagar (Jatropha curcas L) sebagai antibakteri dengan menginaktifkan adesin dan enzim pada sel mikroba. Selain itu, tanin juga menggangu proses transportasi protein di sel lapisan dalam. Pembentukan dinding sel yang kurang sempurna merupakan target tanin pada polipeptida yang mengakibatkan lisisnya sel pada bakteri oleh tekanan fisik dan osmotiknya sehingga kematian pada sel bakteri $\left({ }^{16}\right)$.

Kemudian, terdapat senyawa flavonoid dalam ekstrak daun jarak pagar (Jaropha curcas L). Mekanisme kerja senyawa flavonoid yang berbentuk senyawa komplek protein ekstraseluler dan bersifat polar sehingga dapat merusak membran sel bakteri dan keluarnya senyawa intraseluler. Senyawa flavonoid juga dapat menginhibisi pada sinstesin DNA-RNA dengan cara penumpukan basa nukleat sehingga metabolisme energi terganggu $\left({ }^{17}\right)$. Penghambatan ikatan membran enzim seperti ATPase dan Fosfolipase 2 hal inilah yang menghambat pertumbuhan bakteri. Selain itu terdapat komponen steroida/triterpenoid mekanisme kerjanya mencegah proses pengangkutan ion penting ke dalam sel bakteri $\left({ }^{16}\right)$.

\section{SIMPULAN}

1. Ada efek antibakteri ekstrak daun jarak pagar (Jatropha curcas L) terhadap bakteri Staphylococcus aureus

2. Terjadi peningkatatan rata-rata diameter zona hambat pada setiap perlakuan dengan setiap kenaikan konsentrasi yang diuji. Rerata pada bakteri Staphylococcus aureus nilai diameter hambat dengan konsentrasi 30\%, 50\%, 70\%, $90 \%$ dan $100 \%$ adalah $14,375 \pm 1,5283 \mathrm{~mm}$; $14,450 \pm 2,0091 \mathrm{~mm} ; 14,875 \pm 2,2809 \mathrm{~mm}$; $17,925 \pm 1,8410 \mathrm{~mm} ; 19,800 \pm 1,9155 \mathrm{~mm}$.

3. Tidak ada perbedaan aktivitas antibakteri pada daun jarak pagar (Jatropha curcas Linn) yang menjadi ekstrak terhadap bakteri Staphylococcus aureus

\section{SARAN}

1. Dilakukannya penelitian lanjutan tentang konsentrasi bunuh minimum (KBM) daun jarak pagar (Jatropha curcas Linn) yang menjadi ekstrak terhadap bakteri Staphylococcus aureus.

2. Perlu dilakukan uji antibakteri lainnya dari bagian tanaman jarak pagar (Jatropha curcas Linn) seperti biji, batang dan akar.

\section{DAFTAR PUSTAKA}

1. Ganda Anggara, Gede Pramayu AW. Membangun sistem pakar menggunakan teorema bayes untuk mendiagnosa penyakit paru-paru. Semin Nas Teknol Inf dan Multimed 2016. 2016;79-84.

2. Rahmawati E. Sistem Pakar Diagnosis Penyakit Paru-Paru Menggunakan Metode Forward Chaining. J Tek Elektro. 2016;8(2):64-9.

3. Fauzi R, Handari SRT. Analisis Faktor yang Berhubungan dengan Penggunaan Produk Tembakau Non-Rokok pada Pelajar SMP di Indonesia. Media Kesehat Masy Indones. 2019;15(2):135.

4. World Health Organization. Prioritization of pathogens to guide discovery, research and development of new antibiotics for drugresistant bacterial infections, including tuberculosis. 2017. 25 p.

5. Dahesihdewi A, Sugiani AK, Parwati I. Data Surveilans Mikroba Dan Berdasarkan Tipe Rumah Sakit Di Indonesia Tahun 2017. Dahesihdewi A, Sugiani AK, Parwati I, editors. Jakarta Selatan, Infonesia: Perhimpunan Dokter Spesialis Patologi Klinik dan Kedokteran Laboratorium Indonesia; 2018. 80 p.

6. Setyani W, Setyowati $H$, Ayuningtyas D. 
Pemanfaatan ekstrak terstandardisasi daun som jawa (talinum paniculatum (jacq.) Gaertn) dalam sediaan krim antibakteri Staphylococcus aureus. J Pharm Sci Community. 2016;

7. Setiawati A. Peningkatan Resistensi Kultur Bakteri Staphylococcus aureus terhadap Amoxicillin Menggunakan Metode Adaptif Gradual. J Farm Indones. 2015;7(3):190-4.

8. Apriliana E, Ramadhian MR, Warganegara E, Hasibuan A, Studi P, Dokter $P$, et al. Perbandingan Daya Hambat Ekstrak Daun Jarak Pagar ( Jatropha curcas Linn ) terhadap Pertumbuhan Bakteri Staphylococcus aureus dan Escherichia coli secara In Vitro. J Artik Penelit. 2018;5:556-61.

9. Tiwa FG, Homenta H, Hutagalung BSP. Uji Efektivitas Daya Hambat Getah Daun Jarak Pagar (Jathropa Curcas L.) Terhadap Streptococcus Mutans. Pharmacon. 2017;6(4):192-200.

10.Guranda I, Maulanza H. uji effektfitas tanaman jarak pagar (jatropha curcas I.) sebagai anti mikroorganisme pada bakteri Escherechia coli. j Serambi Saintia. 2016;IV(2):42-9.

11.KEMKES RI. Farmakope Herbal Indonesia Edisi II. 2017. $531 \mathrm{p}$.

12.Utomo SB, Fujiyanti M, Lestari WP, Mulyani S. Antibacterial Activity Test of the C-4methoxyphenylcalix[4]resorcinarene Compound Modified by HexadecyltrimethylammoniumBromide against Staphylococcus aureus and Escherichia coli Bacteria. JKPK (Jurnal Kim dan Pendidik Kim. 2018;3(3):201.

13.Sari R, Muhani M, Fajriaty I. Uji Aktivitas Antibakteri Ekstrak Etanol Daun Gaharu (Aquilaria microcarpa Baill.) Terhadap Bakteri Staphylococcus aureus dan Proteus mirabilis Antibacterial Activity of Ethanolic Leaves Extract of Agarwood (Aquilaria microcarpa Baill.) Against Staphyloco. Pharm Sci Res. 2017;4(3):143-54.

14.Qori Fadillah, Linda Chiuman CNGM. Uji efektivitas antibakteri air perasan jeruk nipis (citrus aurantifolia) terhadap bakteri salmonella typhi pada ikan salmon (oncorhynchus nerka) effectiveness. J biol lingkungan, ind dan kesehatan. 2020;

15. setiawan iwan, erlin euis warsono. Uji Ekstrak Etanol Daun Jarak Pagar (Jatropha curcas L.) Terhadap zona hambat bakteri staphylococcus aureus secara in vitro. J pendidik biol. 2016;4:75-80.

16.Susilo Yulianto SK. Aktivitas antibakteri ekstrak daun jarak pagar (jatropha curcas I) terhadap s taphylococcus epidermidis dan staphylococcus aureus secara in vitro. J Terpadu IImu Kesehat. 2018;60-6.

17.Warganegara E\&, Restina D. Getah jarak (Jatropha curcas L.) sebagai penghambat pertumbuhan bakteri Streptococcus mutans pada karies gigi. Med J Lampung Univ. 2016;5(3):1-6. 